\title{
Micropapillary Transitional Cell Carcinoma
}

National Cancer Institute

\section{Source}

National Cancer Institute. Micropapillary Transitional Cell Carcinoma. NCI Thesaurus.

Code C65182.

A transitional cell carcinoma characterized by a micropapillary growth pattern. Typical example is the micropapillary variant of infiltrating bladder urothelial carcinoma. 